ISSN: 2224-0616

Int. J . Agril. Res. Innov. \& Tech. 8 (1): 26-37, J une, 2018

Available online at http:/ / www.ijarit.webs.com

\title{
ROOT CROPS AGROFORESTRY FOR GREENING THE SUSTAINABILITY OF GREEN REVOLUTION
}

\author{
Y. Widodo ${ }^{*}$, S. Wahyuningsih ${ }^{2}$, J.S. Utomo ${ }^{3}$ and A. Subagio ${ }^{4}$ \\ Received 5 February 2018, Revised 10 June 2018, Accepted 26 June 2018, Published online 30 June 2018
}

\begin{abstract}
Green revolution started at mid of twentieth century was the answer of anxiousness reminded by Malthusian that food scarcity problems in relation with population growth. In concurrence with exploitation of fossil fuel for agriculture mechanization as well as agrochemicals in the form of inorganic fertilizer and pesticide, green revolution by introducing high yielding varieties of cereals and grains was able to nourish the world population by increasing productivity. Indeed, from beginning of mechanization with fossil fuel based as advised by Rudolf Diesel then Arrhenius would be affected to the release of $\mathrm{CO}_{2}$ to the atmosphere and consequently exaggerating climate change as suffered by current and future generations. Under green revolution based on cereals and grains affected forest conversion into open agricultural land, because both commodities are sun-loving crops, which are hate to the shade. On the other hand, to slow the severity of climate change natural forest must be conserved tightly. Entering third millennium demand of food production with ecologically friendly is stronger. Hence, green revolution needs to be amended into greener perspectives. Thus, implementation of agro-forestry into wide range of agro-ecological zone is urgently innovated. Fortunately, shade tolerant of root crops has significant advantage to be developed under agro-forestry. Under shade of forest canopy at basal forest strata, root crops are able to sequester $\mathrm{CO}_{2}$ to be converted into carbohydrate and other compounds to provide food for the dweller. Back to nature is not only a slogan, with root crops under agro-forestry is a reality; fresh root up to $30 \mathrm{t} \mathrm{ha}^{-1}$ can be harvested yearly as the source of food and renewable fuel as well. This potential is very worthy to improve and greening the existing green revolution to be more sustainable.
\end{abstract}

Keywords: Greening Green Revolution, Root Crops Agro-Forestry, Food

${ }^{1}$ Principle Agronomist, Indonesian Legume and Tuber Crops Research Institute (ILETRI), J1. Raya Kendalpayak km 8 P.O Box 66 Malang 65101 Indonesia.

${ }^{2}$ Junior Assistant, Indonesian Legume and Tuber Crops Research Institute (ILETRI), Jl. Raya Kendalpayak km 8 P.O Box 66 Malang 65101 Indonesia.

${ }^{3}$ Director of Indonesian Legume and Tuber Crops Research Institute (ILETRI), Jl. Raya Kendalpayak km 8 P.O Box 66 Malang 65101 Indonesia.

${ }^{4}$ Senior Lecturer, University of Jember, Jl. Kalimantan I Jember 68121, Indonesia.

*Corresponding author's email: yudi_atas@yahoo.com (Y. Widodo)

\section{Introduction}

Definitely, from the late of $18^{\text {th }}$ century Thomas Robert Malthus an economist of British was agonized that progressive of human population would countenance to the food scarcities. Food production tends to increase arithmetically, while human population tends to increase naturally at a quicker geometric rate, Malthus squabbled that it was no revelation that community thus prefer to reduce (or "control") population growth. Community can increase food production, Malthus thought, only by slow, difficult methods such as reclaiming unused land or intensive farming; but they can demonstrate population growth more effectively by marrying late, using contraceptives, emigrating, or in more tremendous circumstances, resorting to condense health care, tolerating vicious social diseases or

impoverished living conditions, warfare, or even infanticide. Malthus was fascinated not with the inevitability of human termination, but with why humans do not die off in the face of such overpowering odds. As an economist, he studied responses to incentives. Based on this theory, therefore, population control by family planning program was widely implied; however, in some developing south countries including Indonesia the population growth is still high. On the other hand, the endeavor to increase food production by the newly technology innovation was also intensively undertaken (Malthus, 1798; Landsburg, 2008). After almost two centuries succeeding Malthus, in order to anticipate food scarcity a plant scientist Norman Ernest Borlaug (a Norman breeder) struggled by improving high 
yielding crop varieties particularly wheat and other cereals followed by better management inputs and mechanization as so called as the green revolution. Borlaug endeavored was able to overcome the food shortage behind periods of second world war, consequently entering sixties and seventies green revolution was widely recommended in Latin America and Asia as well with success story. Capability of Borlaug with green revolution to feed the world was enjoyed by more $50 \%$ population that mostly consumes bread and/or noodle before goes to bed without sufferings hungry. The culmination of Borlaug work was a Noble Peace Prize in 1970 (Landsburg, 2008).

Population growth of Indonesia in the period of 1960 to 1975 was very high above $5 \%$ yearly, so to meet the greater food demand is not easy. Although as tropical archipelago country Indonesia has very diverse of food, however rice is the staple food up to now. In 1985 when the population approximately was 160 million people of Indonesian, after adopting green revolution able to attain rice self-sufficiency. Unfortunately, population today is >261 million people, therefore food insecurity are severe problem (BPS, 2016). Food problem is always faced by Indonesian which often to induce socio-economic as well as political instability. It is a reason green revolution was adopted in order to attain selfsufficiency of food.

\section{Materials and Methods}

To gather the fore mentioned above objective data from many origins of past, present situation as well as prediction of future trend are collected. Empirical experiences and research accomplishment progress as well as worthy information were congregated. To provide adequate information about the potential of root crops to meet the urgent need on food and the other uses, inductive and deductive approaches are executed simultaneously into convergence parity (Burney, 2008). Descriptive research method as elaborated by Hale (2013) is also employed for accomplishing better finding. These two methods can be described into activities as follows:

\section{Learning of Literature}

Appropriate orientations related to root and tuber crops to accomplish food and other uses were collected and understood clearly. References accessed from library as well as on line are executed in this study. Illegible and ambiguous information were evaluated further into detail primary as well as secondary data collected from Ministry of Agriculture, Ministry of Forestry and Indonesia Statistical Agency as well as from World Bank, Food and Agriculture Organization (FAO) of United Nations (UN) and other international institutions under CGIAR such as
Centro Internacional de Agricultura Tropical (CIAT) Cali Columbia, Centro Internacional de la Papa (CIP) La Molina Peru, International Institute for Tropical Agriculture (IITA) Ibadan Nigeria, Centre International Forestry Research (CIFOR) and International Centre Research for Agro-forestry (ICRAF) Bogor Indonesia. Intensive communications with the other authors' national, regional and international levels were actively built in order to clarify proper information through conferences, seminars and workshops as well as discussion via electronic mail (email) in the related field (CIP, 2000; 2001; FAO, 2012; CIAT, 2010).

Arena Reflection

To describe the fact and phenomena the observational method, field survey as well as in depth case study, methods were adopted as suggested by Hale (2013) in order to obtain a better description (including prediction and explanation). Field survey was conducted by multiple visits. A series of multiple visits to root crops niche in the agro-forestry under areas of Perhutani (Forest State Enterprise) at Banten, West J ava, Central J ava and East J ava as well as under forest managed by local communities in Sumatra, Kalimantan, Sulawesi, Nusatenggara till Papua were undertaken during 1995 to 2015. Yield cut survey in line with open ended group discussion were executed during field observation. While in depth case study was undertaken to specific case such as domain research area under Starch Research Centre, Sulusuban Lampung Ministry of Research and Technology. In depth case study was also undertaken by visiting to bio-ethanol factories in Lampung as well as in East Java, which used root crops especially cassava and sweet potato as the raw materials. Experience of first author to collaborate action research for production of sweet potato in Serdang, Tanjung-Karang Lampung under Toyota Bio Indonesia, a Japanese foreign investment during 2004-2007 was also incorporated to obtain better accomplishment. Development sites of cassava plantation in several provinces of Indonesia particularly for bio-ethanol were observed and evaluated as planned in 2007.

Comparative studies by visits to China, Thailand, Vietnam, Malaysia and India as well as Japan, EU Countries in producing bio-ethanol as food competitor raw materials were also incorporated to broaden discussion. As a summary of the methods and approaches used in this study is presented below by flexible process for implementing in the real circumstances. Principally the implementation of this combination method is oriented to achieve the better accomplishment. Check and cross check is intended by focus observation to confirm in order to get valid information is simultaneously undertaken. 


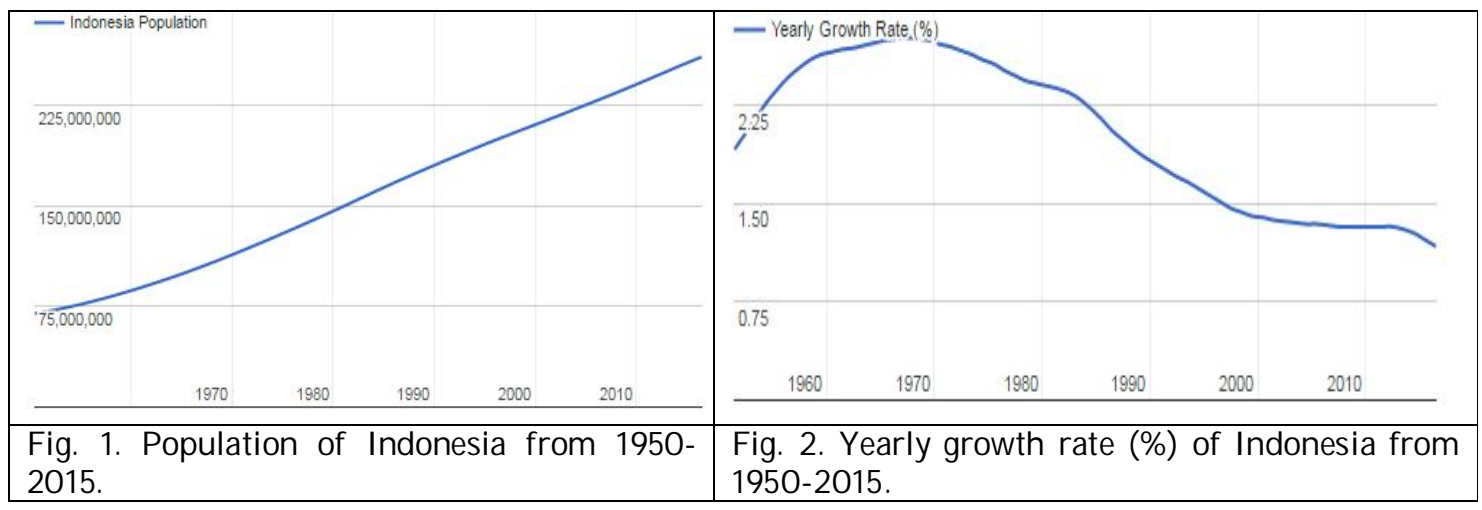

\section{Results and discussion}

\section{Green Revolution from Ideology into Praxis}

Although population growth was decrease compared to the period of 1960-1980, however at rate of $1.5 \%$ making Indonesia population today is $>261$ million people. Uncertainty rice food based supply will persuade a very fragile condition (Fig. 1 \& 2). Recommendation from UNCHR (2000) sustainability of food supply has to consider the ecological aspect. In fact there is an ecological devastation in the form of climate change that severely and notorious problem, which should be handled by global community. Due to climate change, the target of food production was not able to be attained. Therefore, MDGs continued SDGs first objective is to eradicate hunger and alleviate poverty will only as an expectation, which is far from reality. Recent facts indicated that climate change impinge on the huge storm at various sites with four seasons as well as extreme flood and drought in the region with two seasons. The tragic loss of life and staggering upheaval delivered by Hurricane Sandy in the latest example of a dangerous and growing trend of more frequent and intense weather disasters. It is not just the Northeast of USA seeing the brutal effects of climate change - this is happening across the globe, simultaneously alongside with Sandy at Nigeria huge flood also affect to 363 people die and around 5,000 suffering as refugees. In Garut and Sumedang West Java under wet dry season huge rainfall of late September 2016, stimulate landslide as well as flooding and 33 people killed and 24 lost. This condition has detrimental effect to the decrease of food production. As part of global community, Indonesia as tropical country with forest area around 139 million hectares is a potential to be developed for buffering the severity of climate change. Fortunately from REDD (Bali Road Map provide a guidance to hold natural forest to be rigorously conserved, and conversion of natural forest into timber production Reducing Emission from Deforestation and Degradation) as well as for agricultural means are not allowed. On the other hand, peat soil, which rich in organic matter from the accumulation of litter falls, in the forest should also be conserved. Because, from one percent of organic content in the soil is able to sequestrate around 80-90 ton $\mathrm{CO}_{2}$ from atmosphere traps into the soil. In fact, organic matter content in the peat soil could reach $>20 \%$, so the ability of peat soil to avoid global warming or climate change has to be maintained. Currently, peat soil is mined as source of organic matter for agricultural land. So, degradation of peat soil due mainly to exploitation as well as forest conversion will trigger to the increase of $\mathrm{CO}_{2}$ in atmosphere, so heat increase in micro climate and ultimately to be a global warming (Fig. $3 \& 4$ ). Cereal and grain mentality is not merely occupied by decision of policy maker, but it was widely minded by grass root farmers in the hinterlands. Slash and burnt of forest practiced by communities around the forests in preparation of land for food crops especially cereal and grain commodities as well as cassava as pioneer food crop (Fig. 5). 


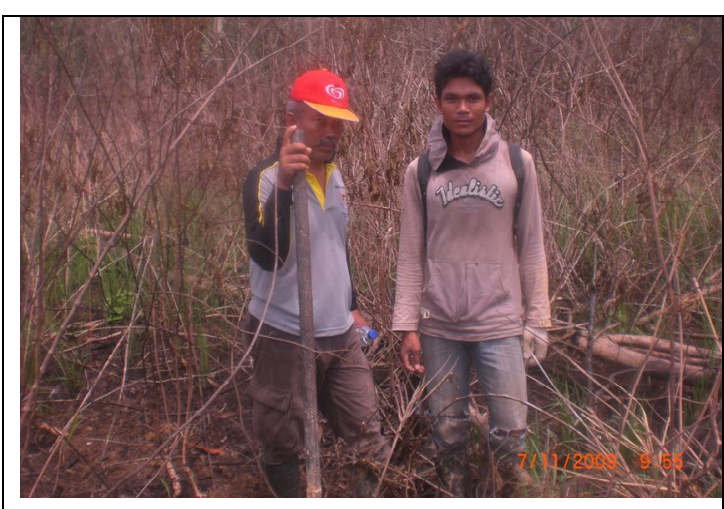

Fig. 3. Effect of fire in the border of forest

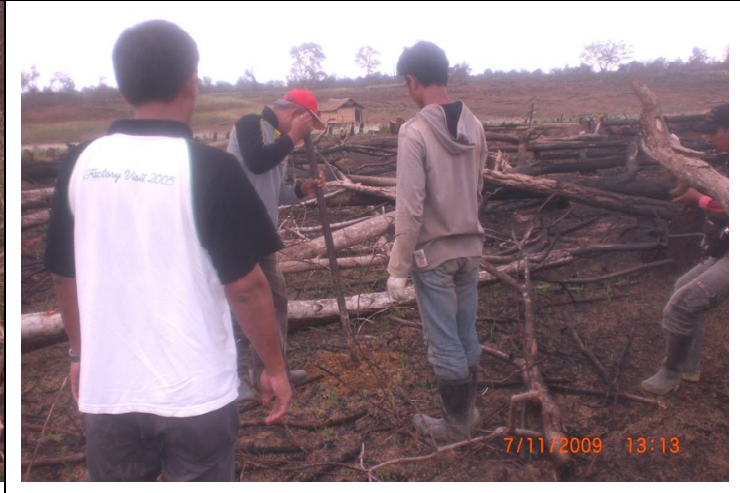

Fig. 4. Fire prevention program is only lip service; it is still widely used illegally.

from slash and burnt activities is not only suffered to the local community, but also fly beyond abroad sphere.

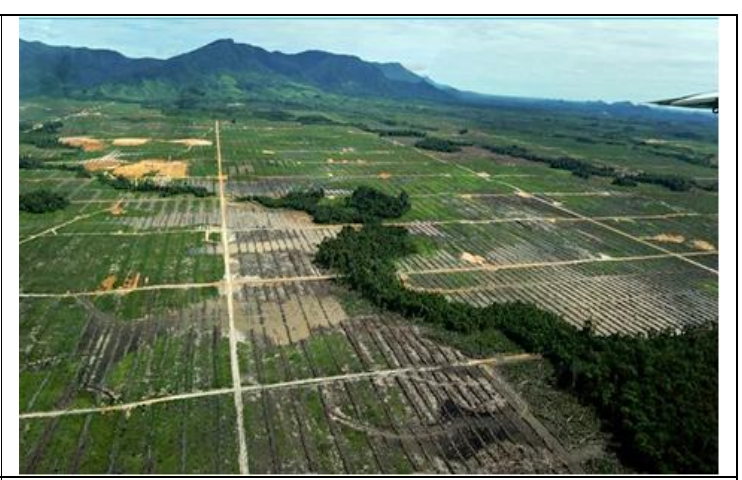

Fig. 6. Conversion of natural forest into the plantation of oil palm area is intensively done in outer island of Java.

Furthermore, Nguyen (2007) also pointed out that from alternative slash and burn for cultivating upland rice inducing or even triggering to deforestation and incrementing the global warming due to the decrease of sink capacity to absorb $\mathrm{CO}_{2}$. Injurious slash and burn to produce food crops could be shift by agroforestry with root crops. Root crops especially from family of Araceae has very good shade tolerant, so under the trees with shade intensity $80 \%$ still able to be grown with reasonable yield. Under such of condition, cereal and grain will not able to grown and not able to produce any edible portion of yield.

At the lowland, rice is the most dominant cereal planted widely by farmers in tropical, subtropical and temperate as well. Rice cultivation is far from ecological sustainability (Kyuma, 1995; Molden, 2002). Under flood condition of lowland rice, organic matter was not completely deteriorated and it results is the release of Methane and Nitrous Oxide from inorganic fertilizer applied. Drought severity and high temperature coincided with global climate change 
is going to be the rigorous problems for securing world rice production (Nguyen, 2007). Moreover, Neue (1993) based on a series of experiments additionally revealed from wetland rice culture, methane was released to biosphere and this had a major detrimental effect to global warming. Methane proportion is around $15 \%$, while $\mathrm{CO}_{2}$ is around $55 \%$ into the total of greenhouse gases, but due to methane can absorb heat latently, so methane emission is more dangerous, and consequently it should be reduced. It is predicted that $20 \%$ of methane in the biosphere is contribution from wetland plus swamp rice culture. Therefore, in order to feed the human population increase, rice cultivation needs an improvement in the newly scheme of green revolution which more ecological orientation.

Root crops, which there yield underground, are suitable to be promoted as potential food source to anticipate climate change (Table 1). There is a wide diversity of root and tuber crops from its environment grouth condition till nutritious content (Bradbury and Holloway, 1988). Therefore, the diversity of root crops could be grown under swampy areas like giant taro till in arid upland under shade root crop like cassava and cocoyam are recommended. Unfortunately, appreciation of community and government to root crops is not proportional and tends to ignore its potency. As consequence, there is no statistical data about harvest area, productivity and production of root crops except on cassava and sweet potato. So, do at the research and extension program, very weak and was not supported by adequate financial plan. It is a reason, investment for shade tolerant root crops grown under agroforestry needs serious support. Agro-forestry with fruit tree species in the tropic is varied and contributes to a significant cash income for the growers as well as to the environment greener.

Table 1. Various root crops grown by farmers in Indonesia.

\begin{tabular}{|c|c|c|c|c|c|}
\hline $\begin{array}{l}\text { Common } \\
\text { name }\end{array}$ & Scientific name and Family & $\begin{array}{l}\text { Altitude } \\
\text { MASL }\end{array}$ & $\begin{array}{c}\text { Temperature } \\
\text { o C }\end{array}$ & $\begin{array}{c}\text { Water } \\
\text { requirement } \\
(\mathrm{mm})\end{array}$ & $\begin{array}{c}\text { Specific } \\
\text { Adaptation }\end{array}$ \\
\hline Cassava & $\begin{array}{l}\text { Manihot esculenta Crantz } \\
\text { Euphorbiaceae }\end{array}$ & $0-1400$ & $15-33$ & $500-2500$ & Humid to Arid \\
\hline Sweet potato & $\begin{array}{l}\text { Ipomea batatas (L.) Lamk } \\
\text { Convolvulaceae }\end{array}$ & $0-3000$ & $10-32$ & $500-2500$ & $\begin{array}{l}\text { Humid to Semi } \\
\text { Arid }\end{array}$ \\
\hline Yam & $\begin{array}{l}\text { Dioscorea spp. L. } \\
\text { Dioscoreaceae }\end{array}$ & $0-2500$ & $15-32$ & $500-3.000$ & Humid to Arid \\
\hline $\begin{array}{l}\text { Elephant } \\
\text { Foot Yam }\end{array}$ & $\begin{array}{l}\text { Amorphophallus Blume ex } \\
\text { Decaisne. Araceae }\end{array}$ & $0-2500$ & $12-32$ & $700-2.000$ & $\begin{array}{l}\text { Humid to Arid } \\
\text { and shade } \\
\text { tolerant }\end{array}$ \\
\hline Taro & $\begin{array}{l}\text { Colocasia esculenta (L.) } \\
\text { Schott. Araceae }\end{array}$ & $0-2700$ & $12-33$ & $700-2.000$ & $\begin{array}{l}\text { Humid to Semi } \\
\text { Arid }\end{array}$ \\
\hline Cocoyam & $\begin{array}{l}\text { Xanthosoma spp. Schott. } \\
\text { Araceae }\end{array}$ & $0-2000$ & $15-33$ & $500-2.000$ & $\begin{array}{l}\text { Humid to Arid } \\
\text { and shade } \\
\text { tolerant }\end{array}$ \\
\hline Swampy taro & $\begin{array}{l}\text { Cyrtosperma merkusii } \\
\text { (Hassk.) Schott Araceae }\end{array}$ & $0-500$ & $22-34$ & $700-3.000$ & $\begin{array}{c}\text { Arid to } \\
\text { swampy areas }\end{array}$ \\
\hline Giant taro & $\begin{array}{l}\text { Alocasia spp. (Schott) G. } \\
\text { Don. Araceae }\end{array}$ & $0-1500$ & $20-34$ & $500-2.000$ & $\begin{array}{l}\text { Humid to Arid, } \\
\text { Shady and } \\
\text { swampy }\end{array}$ \\
\hline Cana root & Canna indica L. Cannaceae & $0-3000$ & $10-32$ & $500-1500$ & $\begin{array}{l}\text { Humid to Arid } \\
\text { shady }\end{array}$ \\
\hline Arrow Root & $\begin{array}{l}\text { Maranta arundinacea L. } \\
\text { Marantaceae }\end{array}$ & $0-1000$ & $18-33$ & $500-2.000$ & $\begin{array}{l}\text { Humid to Arid } \\
\text { shady }\end{array}$ \\
\hline $\begin{array}{l}\text { J ava black } \\
\text { potato }\end{array}$ & $\begin{array}{l}\text { Coleus tuberosus (Glume) } \\
\text { Benthem. Labiatae }\end{array}$ & $0-1000$ & $18-33$ & $700-2.500$ & Humid to Arid \\
\hline Turmeric & $\begin{array}{l}\text { Curcuma domestica (L.) } \\
\text { Zingiberaceae }\end{array}$ & $0-1500$ & 14-32 & $400-1500$ & $\begin{array}{l}\text { Semi arid to } \\
\text { arid shady }\end{array}$ \\
\hline Ginger & $\begin{array}{l}\text { Zingiber oficinale (L.) } \\
\text { Zingiberaceae }\end{array}$ & $0-1500$ & $14-32$ & $400-1500$ & $\begin{array}{l}\text { Semi arid to } \\
\text { arid shady }\end{array}$ \\
\hline $\begin{array}{l}\text { Galangal/ } \\
\text { aromatic } \\
\text { ginger }\end{array}$ & $\begin{array}{l}\text { Kampferia galanga (L.) } \\
\text { Zingiberaceae }\end{array}$ & $0-1500$ & 14-32 & $400-1500$ & $\begin{array}{l}\text { Semi arid to } \\
\text { arid shady }\end{array}$ \\
\hline
\end{tabular}

Source: Widodo (1995a); Flach and Rumawas (1996). 


\section{Incorporating root crops into green revolution}

Introducing of the new high yielding varieties (NHYV) of cereal and grain during green revolution started in 1960 was able to fold over the food production from previously (Satjanata and Partohardjono, 1985). Green revolution encouraging that the increase of food production could be attained to answer the worry from Malthusian. Unfortunately, there was the weakness of NHYV, which mostly are voracious to the nutrients, so application of high inorganic fertilizer, pesticide and other inputs is necessary in order to express the genetic potential of NHYV. Indonesia after around 20 year's adoption of green revolution then was able to attain rice selfsufficiency in 1984. Regrettably, 13 years later Indonesia trapped into food crisis due to production of rice was not balance with the huge consumption, so as consequence import of rice could not be avoided and it is undertaken till today (Sawit, 2002; Saifullah, 2002). Indonesia is the highest rice consumption country worldwide, namely 135 kg/ capita/year (Suparlan, 1992; Simatupang and Fleming, 2001; J ahari and Sumarno, 2002). Therefore, with the population of around 247 million people, government has to make strong endeavor to nourish the citizen by rice. Improving the performance of rice production as consequence to green revolution is done by the increase of productivity from conventional plant breeding as well as biotechnological tool with genetic engineering. From cultural practices by applying more fertilizers as well as neglecting crop rotation, so rice can be harvested four times yearly. In fact, corollary of the harvest intensity to be four times, yield was very low and in some areas, the serious damage due to pest and disease induces to failure of harvest.

Rice as source of food is strongly recommended by government and distribution to the whole country to be easily accessed by all people in order to realize food security. Rice is also distributed by government for the poor under the Program Social Safety Net, which the price paid by poor people only 0.2 USD, because it is subsidized by government. Rice based food pattern significantly induces to the fragile of food security, particularly from diversification. Because, the availability and easily to access rice promotes the people to food source other than rice. So, previously maize, sorghum, root crops are also widely consumed by hinterlands in rural remote areas, all those shifts to consume rice (Saifullah, 2002; Suparlan, 1992; Jahari and Sumarno, 2002). Recently, Indonesia still import of rice mostly from Asian countries. Moreover, in fiscal year of 2013 Indonesia try to negotiate with Cambodia to buy at least 1 million tons of rice to keep national stock. Aside rice, Indonesia also imports soybean, wheat, and maize as well as cassava starch to fulfill the huge domestic consumption. This situation is incredible, because Indonesia as agricultural country still imports many kinds of agricultural goods. In fact Indonesia with huge of natural tropical resource may be able to have significant role in food production not only for domestic need, but also dedicates to feed global hunger community. Due to climate change and unstable political situation, around 35 countries worldwide under malnourish and require attention of international support (FAO, 2012). This situation is challenging the global community to be the safer of climate future in sustaining human civilization by providing food adequately in quantity and in its quality as well. In short source of food discrimination and/ or polarization between cereal and grain better than that of root and tuber crops have to be terminated. Each of crop and plant has advantage and disadvantage to be utilized wisely by the human with their knowledge and science to deliver the newly innovation, so those are complementary to perform into a harmony.

Resolution about root crops is not the dirty food product as well as not as the soil depleting factor was often mentioned into scientific articles by Cock (1985), Falcon et al. (1986), Takagi et al. (1996) and CIP (2000; 2001). Moreover, researches of different scientists revealed that root crops are suitable for poor farmers with ecological friendly practices, because less chemical input required for control of pests and diseases (COPR, 1986; Widodo, 1993, 1995b; CIAT, 2010). Fortunately, in Indonesia in order to improve the performance of food security and self-sufficiency to be food sovereignty released several decrees to promote the indigenous food including root crops that suitable to local natural resources. Furthermore these resolutions require to be implemented into real action under farmers circumstances as production site, trading sector as distribution side, and end user as consumption coincide with ultimate continuum well as. Entry point and focus as priority of SDGs is to eradicate hunger and alleviate poverty, therefore production site under farmer's circumstances has to be urgently undertaken to trigger distribution as well as consumption aspect. Resolution to produce shade tolerant underground root crops under agro-forestry is very suitable with the spirit of global community to adapt and mitigate from climate change. Food aid mostly is dominated by grain and cereal. In fact, food aid from root crops can be distributed and given in the form of flour as intermediate product. Technology for processing of root crops into starch and flour is available. To produce raw material of root crops for processing is suggested by using shade tolerant varieties to be grown under agro-forestry (Villamayor, 1996; Villamayor and Jukema, 1996). Unlike in the agricultural openly field, in agro-forestry mechanization is less suitable to be 
implemented. Root system of trees (forest) is not allowed to damage by mechanical tool of machineries. Therefore, agro-forestry is socially feasible, due to many labors (workers) involve to establish the system. Agro-forestry is alike traditional subsistence, but it is fit with economic claim, because more people able to get job.

Seduction of green revolution from economic sites were adopted by capitalism to invest more in food production by marginalizing poor and traditional farmers. Moreover, green revolution with grains and cereals based was affected to the conversion of natural forest into open agricultural field, due to grain and cereal crops are hesitate to be grown under shade of trees. As consequence, there was the shortage or no trees on farm. Unfortunately, concession food shrill aloud particularly for cereals and grains therefore as consequence green revolution is far from greener environment. The development progress of green revolution praxis tends to encourage the greedy economy in which ecological aspect is almost neglected. There was a huge gap between ideology and praxis in implementing green revolution to be ecological-organically friendly agriculture. Since green revolution is based on high yielding varieties that consumed huge amount of inorganic fertilizers as well as pesticides, both are generated from fossil fuel, which is not renewable anymore. Moreover, pollution from fertilizers and pesticides industry for supporting performance of green revolution disturbing to the worse of environment gradually. As consequence, food produced from the field of green revolution domains are contaminated with unhealthy components such as heavy metals and toxic substances. The current and future trends in order to attain food sovereignty aspect related to security and safety have to be considered paralleled in line with a need of the greener environment imperatively under sustainable platform. Indonesia as part of global community in attempt to feed the current and future population has to be very careful in converting forest into open agricultural field dedicated for food production. Agro-forestry with organic farming are the prospective solution to answer the problem encountered as describe above. Moreover, by agro-forestry in tropical rain forest climate will contribute to undulating landscape missing from erosion and landslide. This paper will elaborate and discuss the advantage and disadvantage agro-forestry, especially for root and tuber crops, which have very good shade tolerant.

\section{Future greener environment}

Individual tree or abundance in the forest has significant role as windbreak to prevent properly the formation of hurricane. Dilution of agricultural field into agro-forestry is going to benefiting many, not only from socio-economic aspect, but also from ecological-sustainability aspect. Unlike investment in economy, evaluation should be made available in a short term. Ecological-sustainability aspect is wider than socio-economic point of view. This aspect is categorized into intangible investment contributed to human civilization because providing food and agricultural product in short term and in long-term keeping future greener of the environment. Recently, there is an indication clearly a numerous of water resource cease directly due to intensive forest logging (Fig. 6). Observation in Central Borneo indicated due to forest conversion to oil palm, rubber plantation etc. flooding always following the huge rain. Drought at dry season and flood at rainy season is a proof of massy handling of forest in Indonesia. Community awareness to recover water resources by keeping greener environment for current and future generation is more strongly developed. As tropical regions with distinguish dry and wet period, therefore establishment of agro-forestry is started at the early of rainy season. The advantage of agro-forestry has to be understood particularly from long-term ecological contribution, so it is not only considered from economic seduction aspect (Fig. $7 \& 8$ ).

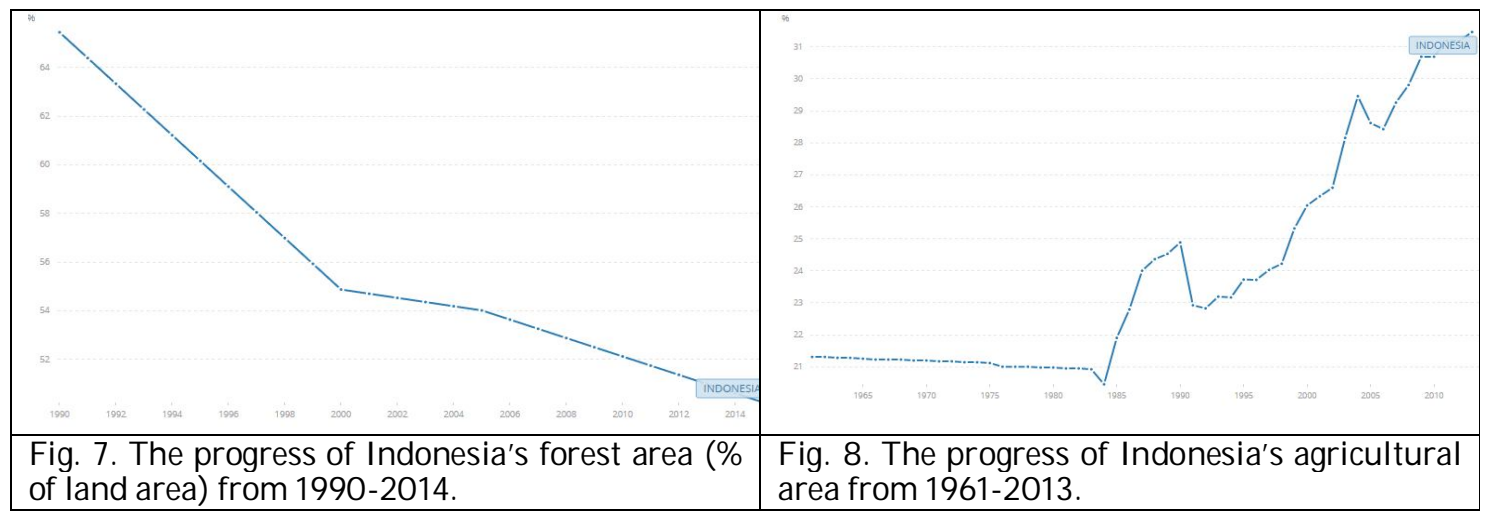

Int. J . Agril. Res. Innov. \& Tech. 8 (1): 26-37, J une, 2018 
Traditionally transfer of knowledge and science was done by farmers across generation (Widodo et al., 1990; Widodo, 2011; 2012). Unfortunately, the methods of education undertaken by farmers to transfer their knowledge and skill were not held in the classroom as done by 'modern education' adopted by Ministry of Education in any countries. Education is a long-term investment; it is needed not only to create knowledge but more to provide real action. Transfer of skill and knowledge of farmers tend to be conducted directly in the field, where they are seeing, doing, and experiencing until believing about innovation. Learning and teaching process in Farmer Field School (FFS) is relatively less talking with minimum book note, but it is more working and doing a practical workload directly in the field. At farmer circumstances, memorandum is in the form of memory banking from their trial and error, then sharing experience fairly to care each other to accomplish the harmony of the community (Widodo, 2012). The way of method and procedure to identify, characterize, describe, and understanding the newly innovation reflecting that farmers in Indonesia especially J ava and Bali are categorized into risk avoider. It could be understood, because farmers in those regions only facilitated by small land tenure around $0.25 \mathrm{ha} /$ household. While in outer islands previously lands and forest available abundantly, these affected to farmer's habit as hunter and gather natural resource products to cover daily life. So, most of small farmers, selecting commodities and varieties planted as well as inputs applied are basic consideration related to gain and losses of agricultural enterprises. On the other hand, market is beyond of farmer's ability, and so far from government is not able to guarantee market of agricultural product, except rice as staple strategic political commodity. It means that aside the severe of climate alteration as well as pest, disease and weed interference, market is as unpredictable factor contributed to risk taking by farmers in the natural resource management. Discovery, development and dissolve the problem encountered then dissemination are a common step wise of farmer learning process from small scale to larger domain. That is the picture reflecting about open-ended and progressive definition of FFS, which tends in rural environment as long life education for dweller.

Tailoring curriculum for FFS special to underground shade tolerant root crops under agro-forestry could be directly undertaken into the specific domain. The worse of deforestation in Indonesia starting at 1998 was able to recover by several agro-forestry works in Java by incorporating root crops into the system. From the progress of root crops under agro-forestry with fully participatory managed by the community around of forest area, the global issues as mentioned above could be attained simultaneously. Adequate or even abundant of food can be harvested from root crops without disturbing the role of forest to avoid the alteration of climate. However, due to cassava, which is the most popular among root crops thus shading effect caused by trees, were mostly reduced by pruning lateral braches to provide more light interception for inducing higher productivity. In fact, to produce fleshy root for cocoyam and elephant foot yam (belong to family of Araceae) are not requiring special treatment to capture the light, even under the rigorous shade of trees those root crops still able to generate edible yield. By assuming $50 \%$ of dry matter is carbon, in the periods of 6-12 months root crops under agroforestry able to sequestrate carbon 5-12 $\mathrm{t} \mathrm{ha}^{-1}$. To anticipate future setback, shade tolerant root crops with more nutritious, high productivity as well as with special trait have to be available easily for the community in order to supply the increase of food and energy demand under greener circumstances of tropical rural environment. Dissemination as part of public education is really required to be intensively undertaken in attempts to trigger the development and utilization of shade tolerant root crops as source of food and energy under future greener rural environment of the tropical regions (Table 1).

Widodo (2012) based on long-term observation in the dynamic process of indigenous knowledge actualization, then suggested about an appropriate curriculum competency base in FFS as so called by EASIER. It is acronym of Empowering Agricultural Solution Initiatives for Economic Reconstruction. The main tool under EASIER program is Participatory Training and Visit (PTV) and then followed by Participatory Technology Development (PTD). PTV is designed and offered to the farmer groups to study by visit the source of innovation such as research institution under government or NonGovernment Organization (NGO), then to the area implementing the newly innovation. Farmers who interest to the newly innovation are allowed to study deeply by involving in the continuum directly, so based on their experiences to follow a training by visit they would freely decide to adopt or modify the newly innovation into their existing circumstances. Incorporation of the newly innovation is through PTD. The reason is for implementing agricultural innovation has to consider the technical feasibility, profitable economically and acceptable socially. Too costly if financial requirement from PTV until PTD to be covered by farmer individually, therefore farmer groups supported 
by government is suggested. Facilitator or instructor under PTD is came from advance domain who is applying the newly innovation. Implementation of PTD is mostly undertaken into small field initially as open field laboratory. Results and yield of harvest from PTD in small scale would be processed or directly go to the market, depended on the existing production, distribution and consumption system.

Recently in Java particularly in suburban areas, in the transition area between agricultural and industrial enterprises, labor and wage for farming are not easily available. Therefore, some areas previously for rice lowland as well as maize upland are planted by fast growing tree species such as Paraserianthes falcataria. Under such condition, cocoyam could be grown under shade of trees. Similar phenomenon also revealed at the complex diverse risk prone area with tropical dry climate, which are mostly as the domain of cassava + maize intercropping as well as sugarcane, some of those areas partly, was reallocated to grow fast growing tree species for timber. Unlike trees for timber, fruit trees such as avocado, jackfruit, breadfruit, durian, mango, rambutan, matoa etc. are also planted to diverse and to improve farmer's income. Under those trees, shade tolerant root crops from the family of Araceae as well as climbing yam Dioscorea sp. could be grown to contribute for additional income (Widodo, 2012).
Flexibility in designing curriculum of agroforestry with emphasize to root crops grown under tree has to be linked with the specific and complexity of tree species cultivated. Under natural forest with only less space remain, cultivation of root crops will not economically profitable. In such condition community around did gathering mushroom or collecting insect for additional nutritious protein. In the area of water resource, natural forest consisted of big and tall trees is strictly kept by community. Production forest for timber with spacing of trees $3 \times 3 \mathrm{~m}$ or 6 $\mathrm{x} 1 \mathrm{~m}$ is allowed to be cultivated for root crops. In early growth of trees, cassava and/ or sweet potato can be grown in between young trees before shading intensity $40 \%$. However, after shading intensity increase till above $60 \%$ alongside with the increase of age and growth of tree canopy, then remaining space under tree could be used to grow cocoyam, arrow root and Cana as well as climbing yam. Under plantation of rubber, oil palm, coconut, cocoa, cashew nut, candle nut, banana and plantain etc. are also possible to be utilized for root crops as under tree for mentioned above (Widodo, 2012; MacDonald, 1982). Unique phenomenon under teak as the best timber quality, shade intensity is only around 6-8 months, because entering dry season leaves senescence will provide more light to root crops grown under teak (Table 2).

Table 2. The area of forest managed by enterprises potential for agro-forestry (2010-2015).

\begin{tabular}{|c|c|c|c|c|c|c|}
\hline \multirow{2}{*}{ Provinces in Indonesia } & \multicolumn{6}{|c|}{ Acreage (ha) } \\
\hline & 2010 & 2011 & 2012 & 2013 & 2014 & 2015 \\
\hline Aceh & 796723 & 524644 & 524644 & 524644 & 409644 & 409644 \\
\hline North Sumatera & 404600 & 294843 & 437393 & 328803 & 328803 & 328803 \\
\hline West Sumatera & 361430 & 268840 & 210376 & 210240 & 210240 & 194290 \\
\hline Riau & 2390457 & 721102 & 812128 & 812128 & 715128 & 318408 \\
\hline $\mathrm{J}$ a mbi & 821995 & 328349 & 299974 & 133705 & 45825 & 45825 \\
\hline South Sumatera & 100000 & 56000 & 56000 & 108170 & 108170 & 108170 \\
\hline Bengkulu & 0 & 23000 & 23000 & 23000 & 23000 & 56070 \\
\hline West Nusa Tenggara & 31550 & 31550 & 31550 & 0 & 0 & 0 \\
\hline West Kalimantan & 1125756 & 1128860 & 1163890 & 1257670 & 1214065 & 1195570 \\
\hline Central Kalimantan & 2825221 & 4323608 & 4569645 & 4473755 & 4120635 & 4086305 \\
\hline South Kalimantan & 280811 & 320531 & 361481 & 359421 & 359361 & 279421 \\
\hline East Kalimantan & 5162452 & 6051172 & 6734227 & 6773357 & 6581712 & 6183873 \\
\hline North Sulawesi & 105500 & 60800 & 60800 & 60800 & 60800 & 60800 \\
\hline Central Sulawesi & 785270 & 1006095 & 992245 & 992245 & 902245 & 854245 \\
\hline South Sulawesi & 409965 & 293407 & 293407 & 0 & 0 & 0 \\
\hline South-east Sulawesi & 296000 & 296000 & 0 & 385590 & 385590 & 385590 \\
\hline Gorontalo & 348200 & 185570 & 185570 & 185570 & 185570 & 145000 \\
\hline West Sulawesi & 0 & 0 & 0 & 293407 & 249407 & 214245 \\
\hline Maluku & 818339 & 785210 & 815165 & 778865 & 554695 & 697195 \\
\hline North Maluku & 306000 & 991000 & 921675 & 983040 & 913040 & 804820 \\
\hline West Papua & 0 & 4512350 & 4350470 & 4091590 & 3560590 & 3885970 \\
\hline Papua & 4042050 & 5512253 & 5581243 & 5495043 & 5241293 & 5516643 \\
\hline Indonesia & 21412319 & 27715184 & 28424883 & 28271043 & 26169813 & 25770887 \\
\hline
\end{tabular}

Source: Forest managed by Enterprises, BPS (2016). 
Table 3. Advantage of agroforestry system in Mount of Kawi, Ampelgading Selorejo Blitar (2012-2017).

\begin{tabular}{|c|c|c|c|}
\hline $\begin{array}{l}\text { Tree forest Year } \\
\text { Planting }\end{array}$ & Plant spacing (m) & Shade(\%) & Rootcrop yield (t ha-1) \\
\hline \multirow[t]{4}{*}{ Mahoni 1997} & $5 \times 2 \mathrm{~m}$ & 70 & Cocoyam $60 x 40 \mathrm{~cm}, 8.5 \mathrm{t} \mathrm{ha}^{-1}$ \\
\hline & $5 \times 2 \mathrm{~m}$ & 70 & Canna edulis, $60 \times 40 \mathrm{~cm}, 9.5 \mathrm{t} \mathrm{ha}^{-1}$ \\
\hline & $5 \times 2 \mathrm{~m}$ & 70 & Arrow root $60 \times 40 \mathrm{~cm}, 6 \mathrm{t} \mathrm{ha}^{-1}$ \\
\hline & $5 \times 2 \mathrm{~m}$ & 70 & Yam100x100 cm, $12 \mathrm{t} \mathrm{ha}^{-1}$ \\
\hline \multirow[t]{4}{*}{ Teak 1995} & $6 \times 4 \mathrm{~m}$ & 60 & Cocoyam $60 x 40 \mathrm{~cm}, 9.75 \mathrm{t} \mathrm{ha}^{-1}$ \\
\hline & $6 \times 4 \mathrm{~m}$ & 60 & Canna edulis $60 \times 40 \mathrm{~cm}, 11 \mathrm{t} \mathrm{ha}^{-1}$ \\
\hline & $6 \times 4 \mathrm{~m}$ & 60 & Arrow root $60 \mathrm{x} 40 \mathrm{~cm}, 6.5 \mathrm{t} \mathrm{ha}^{-1}$ \\
\hline & $6 \times 4 \mathrm{~m}$ & 60 & Yam 100x100 cm, $15 \mathrm{t} \mathrm{ha}^{-1}$ \\
\hline
\end{tabular}

Data collected from farmers in forest area.

Therefore, aside under teak is rich of soil organic matter, it is also more light can be captured by root crops grown under teak, and subsequently edible root yield is obtained. From field observation in Blitar reveals that under teak age 8 years with spacing $3 \times 3 \mathrm{~m}$, root yield of cassava $32 \mathrm{t} \mathrm{ha}^{-1}$ can be harvested. Yield of various rootcrops under shade of forest $70 \%$ and $60 \%$ can be considered high, enough for additional income (Table 3). Fire is the most serious risk under teak area; due to abundance of senescence, leaves are very flame-able. In the more densely populated rural areas around forest is the more risk on fire, because most people are smoker and they are careless to put a remaining fire in the proper place.

Forest fire prevention program should be included into curriculum, by implementing a real demonstration plot in the field. Pond in between trees is an effective tool to avoid fire in the forest. Moreover, pond is also useful to contribute the additional income by nurturing fish such as Tilapia, Gourami and cat fish as well, or snail as source of protein. Implementation of root crops into an integrated agroforestry is obviously able to provide food source of the people.

\section{Conclusion}

Sustainable green revolution as the ideal goal could be attained by investment on agro-forestry as climate safer, so the severely violence of climate change can be avoided. Shade tolerant root crops have a better prospect to be developed alongside with promotion of agro-forestry. So, space remaining under forest trees is able to benefiting many, especially to make available food and other agricultural product as short term economic need as well as long term ecological sustainability for future generation. To design curriculum for FFS in agro-forestry specific and complexity of tree species as well as ecological characters should be described properly. Fruit trees species are recommended to be used in agro-forestry, so there is no timber logging. Under such of condition sequestration of $\mathrm{CO} 2$ and various gases can be properly maintained from fruit trees produced edible fruit, and root crops grown under tree will contribute to additional sequestration, then providing edible underground root for nourishing the population. Additionally to prevent fire in the forest, pond for rearing fish and snail in between trees is suggested. Long life education as follow up to the agro-forestry as climate safer is only a local action, but it has significant contribution to global environment, when it is implemented into larger domains across the continent. Further action to broaden the impact of agro-forestry needs more investment from the donation sources to develop agro-forestry suitable with agro-ecology.

\section{Acknowledgement}

This paper was submitted for discussion at Oslo and Akhersus University (HiOA) on 8-11 June 2017. The authors thank to Perhutani (Forest State Enterprises), ILETRI as well as ATAS Foundation and University of Jember that provide area and financial support to do this activity.

\section{References}

BPS. 2016. Statistic Indonesia. Statistical Year Book of Indonesia. Badan Pusat Statistik Jakarta Indonesia.

Bradbury, J.H. and Holloway, W.D. 1988. Chemistry of Tropical Root Crops: Significance for nutrition and agriculture in the Pacific. Australian Centre for International Agricultural Research (ACIAR) Monograph No. 6, Canberra. 201 p.

Burney, A. 2008. Inductive and Deductive Research Approach. Department of Computer Science, University of Karachi, Pakistan. p. 22.

CIAT. 2010. A New Future for Cassava in Asia: Its Use as Food, Feed and Fuel to Benefit the Poor. Centro Internacional de Agricultura Tropical. Proc. $8^{\text {th }}$ Regional Workshop, held in Vientiane, Lao PDR, Oct 20-24, 2008. $803 \mathrm{p}$.

CIP. 2000. Stories from the field. International Potato Centre. Annual Report 2000. Centro Internacional de la Papa (CIP) Lima Peru. 61 p. 
CIP. 2001 Broadening boundaries in agriculture: Impact on health habitat and hunger. International Potato Centre. Annual Report 2001. Centro Internacional de la Papa (CIP) Lima Peru. $106 \mathrm{p}$.

Cock, J.H. 1985. Cassava New Potential for a Neglected Crop. International Agricultural Development Service. Westview Press Inc., Colorado USA. $191 \mathrm{p}$.

COPR. 1986. Pest Control in Tropical Root Crops. Pans Manual Number 4. Centre for Overseas Pest Research. London. $235 \mathrm{p}$.

Falcon, W.P., Jones, W.O. and Pearson, S.P. 1986. Ekonomi Ubikayu di Jawa (Cassava Economy of Java) Penerbit Sinar Harapan Kerjasamadengan Stanford University Press. Jakarta, $417 \mathrm{p}$.

FAO. 2012. Crops Prospect and Food Situation. Food and Agriculture Organization (FAO), Rome. No 4. p 33. December 2012.

Flach, M. and Rumawas, F. (Eds.) 1996. Plant Resources of South-East Asia No 9. Plants yielding non-seed carbohydrate. Backhuys Publishers, Leiden. 237 p.

Hale, J. 2013. The Three Basic Types of Descriptive Research Methods. Psych Central. Retrieved on February 15, 2013, fromhttp:/ / psychcentral.com/blog/archives /2011/09/27/ the-3-basic-types-ofdescriptive-research-methods/

Jahari, A.B. and Sumarno, I. 2002. Status gizi penduduk Indonesia. Majalah Pangan Media Komunikasi dan Informasi Nomor 38 (XI): 20-29.

Kyuma, K. 1995. Ecological sustainability of the paddy soil-rice system in Asia. Extension Bulletin 413. Food \& Fertilizer Technology Center. Taiwan. $15 \mathrm{p}$.

Landsburg, L.F. 2008. The Concise Encyclopedia of Economics Thomas Robert Malthus (1766-1834). Library Economics and Liberty. Liberty Fund Incorporation.

MacDonald, L.H. 1982. Agro-forestry in the Africa Humid Tropics. Proc. Of a Workshop held in Ibadan Nigeria. 27 April - 1 May 1981. The United Nations University. 171p.

Malthus, T.R. 1798. An Essay on the Principle of Population. 1st ed. 1798, online at the Library of Economics and Liberty, 6th ed. 1826, online at the Library of Economics and Liberty.http:// www.econlib.org/ library/ Mal thus/ malPop.html

Molden, D. 2002. Meeting water needs for food and environmental security. In: M. Yajima, K. Okada and N. Matsumoto (Eds.) Water for sustainable agriculture in developing regions-more crop for every scarce dropJIRCAS Int. Symp. Series No 10. pp. xixXxxii.

Neue, H.U. 1993. Methane emission from rice fields: wetland rice fields make a major contribution in global warming. Biosci. 43 (7): 466-473.

Nguyen, N.V. 2007. Global Climate Change and Rice Food Security. Executive Secretary, International Rice Commission Food and Agriculture Organization (FAO). Rome. pp. 24-30. www.fao.org/ rice/ global climate.

Saifullah, A. 2002. Badan penyangga kebijaksanaan pasar hasil-hasil pertanian dalam usaha menciptakan ketahanan pangan. Majalah Pangan Media Komunikasi dan Informasi Nomor. 38 (11): 30-40.

Satjanata, S. and Partohardjono, S. 1985. Increasing the production of foodcrops in the upland areas in Indonesia. Indonesia Agril. Res. Dev. J. 7 (3 \& 4): 49-53.

Sawit, M.H. 2002. Beras untuk keluarga miskin (RASKIN) : sebuah program perlindungan sosial. Majalah Pangan Media Komunikasi dan Informasi Nomor. 38 (11): 10-19.

Simatupang, P. and Fleming, E. 2001. Food Security Conditions and Problems in South Pacific Island Countries. Palawija News. 18 (2): 5-16.

Suparlan, P. 1992. Kehidupan orang miskin : Kasus di Jakarta. Majalah Pangan Media Komunikasi dan Informasi Nomor. 13 (4): 49-61.

Takagi, H., Kuo, C.G. and Sakamoto, S. 1996. Ipomoea batatas (L.) Lamk. In: Flach, M and Rumawas, F. (Eds.) Plant Resources of South-East Asia No 9. Plants yielding nonseed carbohydrate. Backhuys Publishers, Leiden. pp. 102-107.

UNCHR. 2000. Lembar Fakta, Kampanye Dunia untuk Hak Azasi Manusia. Terjemahan dari Fact Sheet World Campaign for Human Rights, United Nation Decade for Human Rights Education (1995-2005). Diterbitkan oleh Komnas HAM dan British Council, United Nation Center for Human Rights, J akarta. $475 \mathrm{p}$.

Villamayor, F.G. 1996. Agronomic management for sweet potato in the upland agroecology of the Philippines. Paper presented during the Study Tour and Workshop on Agronomic Management of Sweetpotato in Vietnam. 713J anuary 1996. $33 \mathrm{p}$.

Villamayor, F.G. and Jukema, J. 1996. Maranta arundinacea L. In: Flach, M. and Rumawas, F. (Eds.) Plant Resources of South-East Asia No 9. Plants yielding non-seed carbohydrate. Backhuys Publishers, Leiden. pp. 113-116.

Widodo, Y. 1993. Trends of cassava supply and demand and its impact to farmer's income in Lampung Sumatra. In: K.H. Hendroatmodjo, Y. Widodo, Sumarno and B. Guritno (Eds.) Research Accomplishment of Root Crops for Agricultural Development in 
Indonesia. RILET-UNIBRAW-IDRC. pp. 1730.

Widodo, Y. 1995a. Sweetpotato cultivation in a rice-based farming system : the dynamics of indegenous knowledge. In: Jurg Schneider (Ed.) Proc. of an International Workshop on Indegenous Knowledge in Conservation of Crop Genetic Resources. Cisarua Bogor January 30 February 3, 1995. CIP-CRIFC. pp. 105-114.

Widodo, Y. 1995b. Ubi-ubian potensi dan prospeknya untuk dimanfaatkan dalam program diversifikasi. Majalah Pangan Media Komunikasi dan Informasi Nomor. 22 (6): 46-55.

Widodo, Y. 2011. Strategi Sinergistik Peningkatan Produksi Pangan dalam Hutan Lestari Melalui Wanatani. PANGAN Media
Informasi dan Komunikasi BULOG. 20 (3): 251-268.

Widodo, Y. 2012. Food from the forest of Java: tropical agroforestry experiences in feeding dwellers and keeping the environment greener. In: C.A, Brebbia (Ed.) SUSTAINABILITY TODAY. Wessex Institute of Technology (WIT) Press, Southampton, Boston. Printed in UK. pp. 281-393.

Widodo, Y., Hartojo, K., Sunardi, A. and Brotonegoro, S. 1990. Alleviating some agronomic problems of sweet potato in East Java under farmers condition. In: R.H. Howeler (Ed.) Proc. of the 8th Symp. of Int. Soc. of Trop. Root Crops (ISTRC). Oct. 28Nov. 5, 1988. Bangkok, Thailand. pp. 565572. 